\title{
A EDUCAÇÃO NAS CONSTITUIÇÕES FEDERAIS E EM SUAS EMENDAS DE 1824 A 2010*
}

\author{
Nicholas Davies
}

O objetivo deste texto é sistematizar as disposições educacionais contidas nas Constituições federais e em suas emendas de 1824 a 2010 e justifica-se para que os educadores tenham, num único documento, uma visão geral e histórica desta legislação e porque muitas vezes eles se equivocam ao não levar em conta as alterações havidas na legislação (as emendas constitucionais) nem disposições educacionais constantes de outras seções das Constituições, como o Ato das Disposições Constitucionais Transitórias. Um exemplo recente são as emendas constitucionais (conhecidas pelo nome de DRU - desvinculação da receita da União) que, inseridas no Ato das Disposições Constitucionais Transitórias da Constituição de 1988 e, portanto, situadas fora do capítulo educacional, retiraram recursos vinculados à educação, previstos no art. 212 da CF. Só em novembro de 2009 a emenda constitucional 59 revogou os efeitos prejudiciais da DRU para a educação, com vigência parcial a partir de 2009 e definitiva a partir de 2011.

\section{1- Constituição do Império (de 25/3/1824)}

Título VIII (Das Disposições Gerais e Garantias dos Direitos Civis e Políticos dos Cidadãos Brasileiros)

Art. 179. A inviolabilidade dos direitos civis e políticos dos cidadãos brasileiros, que tem por base a liberdade, a segurança individual e a propriedade, é garantida pela Constituição do Império, pela maneira seguinte:

(...) 32) - A instrução primária é gratuita a todos os cidadãos.

33) Colégios e universidades, onde serão ensinados os elementos das ciências, belas-artes e letras

2- Lei 16, de 12/8/1834 (Ato Adicional) - Alterações e adições à Constituição de 1824.

Art. 10. Compete às mesmas Assembléias [provinciais] legislar:

$2^{\circ}$ ) - Sobre instrução pública e estabelecimentos próprios a promovê-la, não compreendendo as faculdades de medicina, os cursos jurídicos, academias atualmente existentes e outros quaisquer estabelecimentos de instrução que, para o futuro, forem criados por lei geral.

$7^{\circ}$ ) (...) São empregos municipais e provinciais todos os que existirem nos Municípios e Províncias, à exceção dos (...) empregados das faculdades de medicina, cursos jurídicos e academias, em conformidade da doutrina do $\S 2^{\circ}$ deste artigo.

\section{3- Constituição de 1891 (24/02/1891)}

Capítulo IV - Das Atribuições do Congresso

Art. 34. Compete privativamente ao Congresso Nacional:

(...) 30) legislar sobre a organização municipal do Distrito Federal, bem como sobre a polícia, o ensino superior e os demais serviços que na Capital forem reservados para o Governo da União.

Art. 35. Incumbe, outrossim, ao Congresso, mas não privativamente:

\footnotetext{
* As informações relativas às Constituições de 1824 a 1967 e suas alterações até 1985 foram extraídas do v. 1 de Constituições do Brasil, editado pela Subsecretaria de Edições Técnicas do Senado Federal, 1986. A Constituição de 1988 e suas alterações foram obtidas no sítio da Presidência da República (www.planalto.gov.br). As emendas constitucionais (ECs) são indicadas em negrito e dentro de caixa.
} 
$2^{\circ}$ ) animar, no País, o desenvolvimento das letras, artes e ciências, bem como a imigração, a agricultura, a indústria e comércio, sem privilégios que tolham a ação dos Governos locais;

$3^{\circ}$ ) criar instituições de ensino superior e secundário nos Estados;

$4^{\circ}$ ) prover a instrução secundária no Distrito Federal.

Título IV - Dos Cidadãos Brasileiros

Art. 70 - $\S 1^{\circ}$ - Não podem alistar-se eleitores para as eleições federais ou para as dos Estados:

$2^{\circ}$ ) os analfabetos.

Seção II - Declaração de Direitos

Art. 72. $\S 6^{\circ}$ - Será leigo o ensino ministrado nos estabelecimentos públicos.

\section{4- Constituição de 1934 (16/07/1934)}

Art. $5^{\circ}$. Compete privativamente à União:

XIV - traçar as diretrizes da educação nacional.

Art. $10^{\circ}$. Compete concorrentemente à União e aos Estados:

VI - difundir a instrução pública em todos os seus graus.

Art. 108. Parágrafo único - Não se podem alistar eleitores:

a) os que não saibam ler e escrever.

Dos Direitos e das Garantias Individuais

Art. 113 - A Constituição assegura a brasileiros e estrangeiros residentes no País a inviolabilidade dos direitos concernentes à liberdade, à subsistência, à segurança individual e à propriedade, nos termos seguintes:

36) Nenhum imposto gravará diretamente a profissão de escritor, jornalista ou professor.

\section{Título IV - Da Ordem Econômica e Social}

Art. 139. Toda empresa industrial ou agrícola, fora dos centros escolares, e onde trabalharem mais de cinqüenta pessoas, perfazendo estas e os seus filhos, pelo menos, dez analfabetos, será obrigada a lhes proporcionar ensino primário gratuito.

Título V - Da Família, da Educação e da Cultura

Capítulo II - Da Educação e da Cultura

Art. 148. Cabe à União, aos Estados e aos Municípios favorecer e animar o desenvolvimento das ciências, das artes, das letras e da cultura em geral, proteger os objetos de interesse histórico e o patrimônio artístico do País, bem como prestar assistência ao trabalhador intelectual.

Art. 149. A educação é direito de todos e deve ser ministrada pela família e pelos Poderes Públicos, cumprindo a estes proporcioná-la a brasileiros e a estrangeiros domiciliados no País, de modo que possibilite eficientes fatores da vida moral e econômica da Nação, e desenvolva num espírito brasileiro a consciência da solidariedade humana.

Art. 150. Compete à União:

a) fixar o plano nacional de educação, compreensivo do ensino de todos os graus e ramos, comuns e especializados; e coordenar e fiscalizar a sua execução em todo o território do País;

b) determinar as condições de reconhecimento oficial dos estabelecimentos de ensino secundário e complementar deste e dos institutos de ensino superior, exercendo sobre eles a necessária fiscalização; 
c) organizar e manter, nos Territórios, sistemas educativos apropriados aos mesmos;

d) manter no Distrito Federal ensino secundário e complementar deste, superior e universitário;

e) exercer ação supletiva onde se faça necessária por deficiência de iniciativa ou de recursos e estimular a obra educativa em todo o País, por meio de estudos, inquéritos, demonstrações e subvenções.

Parágrafo único - O plano nacional de educação constante da lei federal nos termos dos arts. $5^{\circ}, \mathrm{n}^{\circ}$ XIV, e 39, no 8, letras "a" e "e", só se poderá renovar em prazos determinados, e obedecerá às seguintes normas:

a) ensino primário integral gratuito e de freqüência obrigatória extensivo aos adultos;

b) tendência à gratuidade do ensino educativo ulterior ao primário, a fim de o tornar mais acessível;

c) liberdade de ensino em todos os graus e ramos, observadas as prescrições da legislação federal e da estadual;

d) ensino, nos estabelecimentos particulares, ministrado no idioma pátrio, salvo o de línguas estrangeiras;

e) limitação da matrícula à capacidade didática do estabelecimento e seleção por meio de provas de inteligência e aproveitamento, ou por processos objetivos apropriados à finalidade do curso;

f) reconhecimento dos estabelecimentos particulares de ensino somente quando assegurarem a seus professores a estabilidade, enquanto bem servirem, e uma remuneração condigna.

Art. 151. Compete aos Estados e ao Distrito Federal organizar e manter sistemas educativos nos territórios respectivos, respeitadas as diretrizes estabelecidas pela União.

Art. 152. Compete precipuamente ao Conselho Nacional de Educação, organizado na forma da lei, elaborar o plano nacional de educação para ser aprovado pelo Poder Legislativo e sugerir ao Governo as medidas que julgar necessárias para a melhor solução dos problemas educativos bem como a distribuição adequada dos fundos especiais.

Parágrafo único - Os Estados e o Distrito Federal, na forma das leis respectivas e para o exercício da sua competência na matéria, estabelecerão Conselhos de Educação com funções similares às do Conselho Nacional de Educação e departamentos autônomos de administração do ensino.

Art. 153. O ensino religioso será de freqüência facultativa e ministrado de acordo com os princípios da confissão religiosa do aluno manifestada pelos pais ou responsáveis e constituirá matérias dos horários nas escolas públicas primárias, secundárias, profissionais e normais.

Art. 154. Os estabelecimentos particulares de educação gratuita primária ou profissional, oficialmente considerados idôneos, serão isentos de qualquer tributo.

Art. 155. É garantida a liberdade de cátedra.

Art. 156. A União e os Municípios aplicarão nunca menos de dez por cento, e os Estados e o Distrito Federal nunca menos de vinte por cento, da renda resultante dos impostos na manutenção e no desenvolvimento dos sistemas educativos.

Parágrafo único - Para a realização do ensino nas zonas rurais, a União reservará, no mínimo, vinte por cento das cotas destinadas à educação no respectivo orçamento anual.

Art. 157. A União, os Estados e o Distrito Federal reservarão uma parte dos seus patrimônios territoriais para a formação dos respectivos fundos de educação.

$\S 1^{\circ}$ - As sobras das dotações orçamentárias, acrescidas das doações, percentagens sobre o produto de vendas de terras públicas, taxas especiais e outros recursos financeiros, constituirão, na União, nos Estados, e nos Municípios, esses fundos especiais, que serão aplicados exclusivamente em obras educativas, determinadas em lei.

$\S 2^{\circ}$ - Parte dos mesmos fundos se aplicará em auxílios a alunos necessitados, mediante fornecimento gratuito de material escolar, bolsas de estudo, assistência alimentar, dentária e médica, e para vilegiaturas. 
Art. 158. É vedada a dispensa de concurso de títulos e provas no provimento dos cargos do magistério oficial, bem como, em qualquer curso, a de provas escolares de habilitação, determinadas em lei ou regulamento.

$\S 1^{\circ}$ - Podem, todavia, ser contratados, por tempo certo, professores de nomeada, nacionais ou estrangeiros.

$\S 2^{\circ}$ - Aos professores nomeados por concurso para os institutos oficiais, cabem as garantias de vitaliciedade e de inamovibilidade nos cargos, sem prejuízo do disposto no Título VII. Em casos de extinção da cadeira, será o professor aproveitado na regência de outra em que se mostre habilitado.

Título VII - Dos funcionários públicos

Art. 172. É vedada a acumulação de cargos públicos remunerados da União, dos Estados e dos Municípios.

$\S 1^{\circ}$ - Excetuam-se os cargos do magistério e técnico-científicos, que poderão ser exercidos cumulativamente, ainda que por funcionário administrativo, desde que haja compatibilidade dos horários de serviço.

Disposições transitórias

Art. 20. Os professores dos institutos oficiais de ensino superior, destituídos dos seus cargos desde outubro de 1930, terão garantidas a inamovibilidade, a vitaliciedade e a irredutibilidade dos vencimentos.

\section{5- Constituição de 1937 (de 10/11/1937)}

Art. 15. Compete privativamente à União:

IX - fixar as bases e determinar os quadros da educação nacional, traçando as diretrizes a que deve obedecer a formação física, intelectual e moral da infância e da juventude.

Art. 16. Compete privativamente à União o poder de legislar sobre as seguintes matérias:

XXIV - diretrizes de educação nacional

Art. 117. Parágrafo único - Não podem alistar-se eleitores:

a) os analfabetos.

Da Família

Art. 125. A educação integral da prole é o primeiro dever e o direito natural dos pais. O Estado não será estranho a esse dever, colaborando, de maneira principal ou subsidiária, para facilitar a sua execução ou suprir as deficiências e lacunas da educação particular.

Art. 127. (...) O abandono moral, intelectual ou físico da infância e da juventude importará falta grave dos responsáveis por sua guarda e educação, e cria ao Estado o dever de provê-las do conforto e dos cuidados indispensáveis à preservação física e moral.

Aos pais miseráveis assiste o direito de invocar o auxílio e proteção do Estado para a subsistência e educação de sua prole.

\section{Da Educação e da Cultura}

Art. 128. A arte, a ciência e o ensino são livres à iniciativa individual e à de associações ou pessoas coletivas públicas e particulares.

É dever do Estado contribuir, direta e indiretamente, para o estímulo e desenvolvimento de umas e de outro, favorecendo ou fundando instituições artísticas, científicas e de ensino.

Art. 129. À infância e à juventude, a que faltarem os recursos necessários à educação em instituições particulares, é dever da Nação, dos Estados e dos Municípios assegurar, pela fundação de instituições públicas de ensino em todos os seus graus, a possibilidade de receber uma educação adequada às suas faculdades, aptidões e tendências vocacionais. 
O ensino pré-vocacional e profissional destinado às classes menos favorecidas é em matéria de educação o primeiro dever do Estado. Cumpre-lhe dar execução a esse dever, fundando institutos de ensino profissional e subsidiando os de iniciativa dos Estados, dos Municípios e dos indivíduos ou associações particulares e profissionais.

É dever das indústrias e dos sindicatos econômicos criar, na esfera da sua especialidade, escolas de aprendizes, destinadas aos filhos de seus operários ou de seus associados. A lei regulará o cumprimento desse dever e os poderes que caberão ao Estado sobre essas escolas, bem como os auxílios, facilidades e subsídios a lhes serem concedidos pelo Poder Público.

Art. 130. O ensino primário é obrigatório e gratuito. A gratuidade, porém, não exclui o dever de solidariedade dos menos para com os mais necessitados; assim, por ocasião da matrícula, será exigida aos que não alegarem, ou notoriamente não puderem alegar escassez de recursos, uma contribuição módica e mensal para a caixa escolar.

Art. 131. A educação física, o ensino cívico e o de trabalhos manuais serão obrigatórios em todas as escolas primárias, normais e secundárias, não podendo nenhuma escola de qualquer desses graus ser autorizada ou reconhecida sem que satisfaça aquela exigência.

Art. 132. O Estado fundará instituições ou dará o seu auxílio e proteção às fundadas por associações civis, tendo umas e outras por fim organizar para a juventude períodos de trabalho anual nos campos e oficinas, assim como promover-lhe a disciplina moral e o adestramento físico, de maneira a prepará-la ao cumprimento dos seus deveres para com a economia e a defesa da Nação.

Art. 133. O ensino religioso poderá ser contemplado como matéria de curso ordinário das escolas primárias, normais e secundárias. Não poderá, porém, constituir objeto de obrigação dos mestres ou professores, nem de freqüência compulsória por parte dos alunos.

6- Decreto-Lei 1.202, de 8/4/1939 (também chamado de "Ato Adicional à Constituição de 1937", o decreto dispõe sobre a administração dos Estados e Municípios).

Art. 32. Terão a sua vigência condicionada à aprovação do Presidente da República os decretos-lei [de Estados e Municípios] que dispuserem, no todo ou em parte, sobre:

VII - escolas de grau secundário e superior, e regulamentação, no todo ou em parte, do ensino de qualquer grau.

VII - escolas de grau secundário, normal, profissional e superior, e regulamentação, no todo ou em parte do ensino de qualquer grau. (alterado pelo Decreto-Lei 5.511, de 21/5/43)

Art. 33. É vedado ao Estado e ao Município:

$8^{\circ}$ ) impor, ao exercício das artes e das ciências e ao seu ensino, restrições que não estejam expressas na lei federal;

$9^{\circ}$ ) incorporar à receita as contribuições prestadas pelos alunos das escolas de ensino primário, na forma do art. 130 da Constituição.

Art. 53. Parágrafo único. Todas as escolas, públicas ou particulares, são obrigadas a possuir, em lugar de honra, a bandeira nacional, e prestar-lhe homenagem nos dias de festa oficial (...).

\section{7- Constituição de 1946 (de 18/09/1946)}

Art. $5^{\circ}$. Compete à União:

(...) XV - legislar sobre:

(...) d) diretrizes e bases da educação nacional.

Art. $6^{\circ}$. A competência federal para legislar sobre as matérias do art. $5^{\circ}, \mathrm{n}^{\circ} \mathrm{XV}$, letras (...) d, não exclui a legislação estadual supletiva ou complementar.

Art. 31. À União, aos Estados, ao Distrito Federal e aos Municípios é vedado:

$\mathrm{V}$ - lançar impostos sobre: 
b) templos de qualquer culto, bens e serviços de Partidos Políticos, instituições de educação e de assistência social, desde que as suas rendas sejam aplicadas integralmente no País para os respectivos fins.

Art. 31. É vedado à União, aos Estados, ao Distrito Federal e aos Municípios:

IV - Cobrar impostos sobre:

c) o patrimônio, a renda ou serviços de Partidos Políticos e de instituições de educação ou de assistência social, observados os requisitos fixados em lei complementar. (Alterado pela EC 18, de $1 / 12 / 65)$.

Art. 132. Não podem alistar-se eleitores:

I - os analfabetos.

Capítulo II - Da Educação e da Cultura

Art. 166. A educação é direito de todos e será dada no lar e na escola. Deve inspirar-se nos princípios de liberdade e nos ideais de solidariedade humana.

Art. 167. O ensino dos diferentes ramos será ministrado pelos Poderes Públicos e é livre à iniciativa particular, respeitadas as leis que o regulem.

Art. 168. A legislação do ensino adotará os seguintes princípios:

I - o ensino primário é obrigatório e só será dado na língua nacional;

II - o ensino primário oficial é gratuito para todos; o ensino oficial ulterior ao primário sê-lo-á para quantos provarem falta ou insuficiência de recursos;

III - as empresas industriais, comerciais e agrícolas em que trabalhem mais de cem pessoas, são obrigadas a manter ensino primário gratuito para os seus servidores e os filhos destes;

IV - as empresas industriais e comerciais são obrigadas a ministrar, em cooperação, aprendizagem aos seus trabalhadores menores, pela forma que a lei estabelecer, respeitados os direitos dos professores;

V - o ensino religioso constitui disciplina dos horários das escolas oficiais, é de matrícula facultativa e será ministrado de acordo com a confissão religiosa do aluno, manifestada por ele, se for capaz, ou pelo seu representante legal ou responsável;

VI - para o provimento das cátedras, no ensino secundário oficial e no superior oficial ou livre, exigir-se-á concurso de títulos e provas. Aos professores admitidos por concurso de títulos e provas, será assegurada a vitaliciedade.

VII - é garantida a liberdade de cátedra.

Art. 169. Anualmente, a União aplicará nunca menos de dez por cento, e os Estados, o Distrito Federal e os Municípios, nunca menos de vinte por cento da renda resultante dos impostos na manutenção e desenvolvimento do ensino.

Art. 170. A União organizará o sistema federal de ensino e o dos Territórios.

Parágrafo único - O sistema federal de ensino terá caráter supletivo, estendendo-se a todo o País nos estritos limites das deficiências locais.

Art. 171. Os Estados e o Distrito Federal organizarão os seus sistemas de ensino.

Parágrafo único - Para o desenvolvimento desses sistemas, a União cooperará com auxílio pecuniário, o qual, em relação ao ensino primário, provirá do respectivo Fundo Nacional.

Art. 172. Cada sistema de ensino terá obrigatoriamente serviços de assistência educacional que assegurem aos alunos necessitados condições de eficiência escolar.

Art. 173. As ciências, as letras e as artes são livres.

Art. 174. O amparo à cultura é dever do Estado. 
Parágrafo único - A lei promoverá a criação de institutos de pesquisa, de preferência junto aos estabelecimentos de ensino superior.

Título VIII - Dos Funcionários Públicos

Art. 185. É vedada a acumulação de quaisquer cargos, exceto a prevista no art. $96, \mathrm{n}^{\circ} 1$, e a de dois cargos de magistério ou a de um destes com outro técnico ou científico, contanto que haja correlação de matérias e compatibilidade de horário.

Art. 185. É vedada a acumulação de cargos, no Serviço Público federal, estadual, municipal ou dos Territórios e Distrito Federal, bem como em entidades autárquicas, parestatais ou sociedade de economia mista, exceto a prevista no art. $96, \mathrm{n}^{\circ} \mathrm{I}$, a de dois cargos de magistério, ou a de um destes com outro técnico ou científico ou, ainda, a de dois destinados a médicos, contanto que haja correlação de matérias e compatibilidade de horário (Alterado pela EC 20, de 25/5/66)

Art. 187. São vitalícios somente os magistrados, os Ministros do Tribunal de Contas, os titulares de Ofício de Justiça e os professores catedráticos.

Disposições gerais

Art. 203. Nenhum imposto gravará diretamente os direitos de autor, nem a remuneração de professores e jornalistas.

8- Constituição de 1967 (de 24/1/1967). As alterações foram, em sua maioria, introduzidas pela Emenda Constitucional 1, de 17/10/69; e outras pela EC 12, de 17/10/78, EC 18, de 30/6/81, EC 24 , de $1 / 12 / 83$, e EC 25 , de $15 / 5 / 85$, todas assinaladas em negrito)

Art. $8^{\circ}$. Compete à União: (...)

XIV - estabelecer planos nacionais de educação e de saúde.

XIV - estabelecer e executar planos nacionais de educação e de saúde, bem como planos regionais de desenvolvimento. (alterado pela $\mathrm{EC} 1$ )

XVII - legislar sobre: (...)

q) diretrizes e bases da educação nacional;

$\S 2^{\circ}$ - A competência da União não exclui a dos Estados para legislar supletivamente sobre as matérias das letras (...) "q" do item XVII, respeitada a lei federal.

Capítulo III - Dos Estados e Municípios

Art. 15, $\S 3^{\circ}$ - A intervenção nos Municípios será regulada na Constituição do Estado, somente podendo ocorrer quando:

f) não tiver havido aplicação, no ensino primário, em cada ano, de vinte por cento, pelo menos, da receita tributária municipal. (acrescentado pela EC 1)

Art. 20. É vedado à União, aos Estados, ao Distrito Federal e aos Municípios:

III - criar imposto sobre:

c) o patrimônio, a renda ou os serviços de Partidos Políticos e de instituições de educação ou de assistência social, observados os requisitos fixados em lei.

Capítulo VII - Seção VII - Dos Funcionários Públicos

Art. 97. É vedada a acumulação remunerada, exceto:

Art. 99. É vedada a acumulação remunerada de cargos e funções públicas, exceto: (alterado pela EC 1) 
I - a de Juiz e um cargo de Professor;

II - a de dois cargos de Professor;

III - a de um cargo de Professor com outro técnico ou científico; (...)

$\S 1^{\circ}$ - Em qualquer dos casos, a acumulação somente é permitida quando haja correlação de matérias e compatibilidade de horários.

$\S 1^{\circ}$ - Em qualquer dos casos, a acumulação somente será permitida quando houver correlação de matérias e compatibilidade de horários. (alterado pela EC 1)

$\S 2^{\circ}$ - A proibição de acumular se estende a cargos, funções ou empregos em autarquias, empresas públicas e sociedades de economia mista.

$\S 3^{\circ}$ - A proibição de acumular proventos não se aplica aos aposentados, quanto ao exercício de mandato eletivo, cargo em comissão ou ao contrato para prestação de serviços técnicos ou especializados.

$\S 4^{\circ}$ - A proibição de acumular proventos não se aplica aos aposentados, quanto ao exercício de mandato eletivo, quanto ao de um cargo em comissão ou quanto a contrato para prestação de serviços técnicos ou especializados. (alterado pela EC 1)

Art. $142, \S 3^{\circ}$ - Não podem alistar eleitores:

a) os analfabetos.

Art. 147, $\S 3^{\circ}$ - Não poderão alistar-se eleitores:

a) os analfabetos. (alterado pela EC 1 )

Art. 147, $\S 4^{\circ}$ - A lei disporá sobre a forma pela qual possam os analfabetos alistar-se eleitores e exercer o direito de voto.

Art. 150 - São inelegíveis os inalistáveis e os analfabetos.

(alterado pela EC 25, de 15/5/85)

\section{Título III - Da Ordem Econômica e Social}

Art. 165. A Constituição assegura aos trabalhadores os seguintes direitos, além de outros que, nos termos da lei, visem à melhoria de sua condição social:

XX - a aposentadoria para o professor após 30 anos e, para a professora, após 25 anos de efetivo exercício em funções de magistério, com salário integral. (acrescentado pela EC 18, de $30 / 6 / 81)$

Art. único (após parágrafo único do Art. 165) - É assegurado aos deficientes a melhoria de sua condição social e econômica, especialmente mediante:

I - educação especial e gratuita (...) (acrescentado pela EC 12, de 17/10/78)

Título IV - Da Família, da Educação e da Cultura

Art. 168. A educação é direito de todos e será dada no lar e na escola; assegurada a igualdade de oportunidade, deve inspirar-se no princípio da unidade nacional e nos ideais de liberdade e de solidariedade humana.

Art. 175. $\S 4^{\circ}$ Lei especial disporá sobre a assistência à maternidade, à infância e à adolescência e sobre a educação de excepcionais. (acrescentada pela EC 1) 
Art. 176. A educação, inspirada no princípio da unidade nacional e nos ideais de liberdade e solidariedade humana, é direito de todos e dever do Estado, e será dada no lar e na escola. (alterada pela EC 1)

$\S 1^{\circ}$ - O ensino será ministrado nos diferentes graus pelos Poderes Públicos.

$\S 2^{\circ}$ - Respeitadas as disposições legais, o ensino é livre à iniciativa particular, a qual merecerá o amparo técnico e financeiro dos Poderes Públicos, inclusive bolsas de estudo.

$\S 2^{\circ}$ - Respeitadas as disposições legais, o ensino é livre à iniciativa particular, a qual merecerá o amparo técnico e financeiro dos Poderes Públicos, inclusive mediante bolsas de estudo. (alterado pela EC 1)

$\S 3^{\circ}$ - A legislação do ensino adotará os seguintes princípios e normas:

I - o ensino primário somente será ministrado na língua nacional;

II - o ensino dos sete aos quatorze anos é obrigatório para todos e gratuito nos estabelecimentos primários oficiais;

II - o ensino primário é obrigatório para todos, dos sete aos quatorze anos, e gratuito nos estabelecimentos oficiais; (alterado pela EC 1)

III - o ensino oficial ulterior ao primário será, igualmente, gratuito para quantos, demonstrando efetivo aproveitamento, provarem falta ou insuficiência de recursos. Sempre que possível, o Poder Público substituirá o regime de gratuidade pelo de concessão de bolsas de estudo, exigido o posterior reembolso no caso de ensino de grau superior;

III - o ensino público será igualmente gratuito para quantos, no nível médio e no superior, demonstrarem efetivo aproveitamento e provarem falta ou insuficiência de recursos; (alterado pela EC 1)

IV - O Poder Público substituirá, gradativamente, o regime de gratuidade no ensino médio e no superior pelo sistema de concessão de bolsas de estudo, mediante restituição, que a lei regulará; (alterado pela EC 1)

IV - o ensino religioso, de matrícula facultativa, constituirá disciplina dos horários normais das escolas oficiais de grau primário e médio;

V - o ensino religioso, de matrícula facultativa, constituirá disciplina dos horários normais das escolas oficiais de grau primário e médio; (alterado pela EC 1)

$\mathrm{V}$ - o provimento dos cargos iniciais e finais das carreiras do magistério de grau médio e superior será feito, sempre mediante prova de habilitação, consistindo em concurso público de provas e títulos quando se tratar de ensino oficial;

VI - o provimento dos cargos iniciais e finais das carreiras do magistério de grau médio e superior será feito, sempre mediante prova de habilitação, consistindo em concurso público de provas e títulos quando se tratar de ensino oficial; e (alterado pela EC 1)

VI - é garantida a liberdade de cátedra.

VII - a liberdade de comunicação de conhecimentos no exercício do magistério, ressalvado o disposto no art. 154. (acrescentado pela EC 1) [Art. 154 - O abuso de direito individual ou político, com o propósito de subversão do regime democrático ou de corrupção, importará a suspensão daqueles direitos de dois a dez anos (...)]

$\S 4^{\circ}$ - Anualmente, a União aplicará nunca menos de treze por cento, e os Estados, o Distrito Federal e os Municípios, vinte e cinco por cento, no mínimo, da receita resultante de impostos, na manutenção e desenvolvimento do ensino. (acrescentado pela EC 24, de 1/12/83)

Art. 169. Os Estados e o Distrito Federal organizarão os seus sistemas de ensino, e a União, os dos Territórios, assim como o sistema federal, o qual terá caráter supletivo e se estenderá a todo o País, nos estritos limites das deficiências locais. 
Art. 177. Os Estados e o Distrito Federal organizarão os seus sistemas de ensino, e a União, os dos Territórios, assim como o sistema federal, o qual terá caráter supletivo e se estenderá a todo o País, nos estritos limites das deficiências locais. (alterado pela EC 1)

$\S 1^{\circ}$ - A União prestará assistência técnica e financeira para o desenvolvimento dos sistemas estaduais e do Distrito Federal.

$\S 2^{\circ}$ - Cada sistema de ensino terá, obrigatoriamente, serviços de assistência educacional que assegurem aos alunos necessitados condições de eficiência escolar.

Art. 170. As empresas comerciais, industriais e agrícolas são obrigadas a manter, pela forma que a lei estabelecer, o ensino primário gratuito de seus empregados e dos filhos destes.

Art. 178. As empresas comerciais, industriais e agrícolas são obrigadas a manter o ensino primário gratuito de seus empregados e o ensino dos filhos destes, entre os sete e os quatorze anos, ou a concorrer para aquele fim, mediante a contribuição do salário-educação, na forma que a lei estabelecer. (alterado pela EC 1)

Parágrafo único - As empresas comerciais e industriais são ainda obrigadas a ministrar, em cooperação, aprendizagem aos seus trabalhadores menores.

Parágrafo único - As empresas comerciais e industriais são ainda obrigadas a assegurar, em cooperação, condições de aprendizagem aos seus trabalhadores menores e a promover o preparo de seu pessoal qualificado. (alterado pela EC 1)

Art. 171. As ciências, as letras e as artes são livres.

Art. 179. As ciências, as letras e as artes são livres, ressalvado o disposto no parágrafo $8^{\circ}$ do Art. 153. (alterado pela EC 1) $\left[\S 8^{\circ}\right.$ do Art. 153: É livre a manifestação de pensamento, de convicção política ou filosófica, bem como a prestação de informação independentemente de censura, salvo quanto a diversões e espetáculos públicos, respondendo, cada um, nos termos da lei, pelos abusos que cometer. É assegurado o direito de resposta. A publicação de livros, jornais e periódicos não depende de licença da autoridade. Não serão, porém, toleradas a propaganda de guerra, de subversão da ordem ou de preconceitos de religião, de raça ou de classe, e as publicações e exteriorizações contrárias à moral e aos bons costumes].

Parágrafo único - O Poder Público incentivará a pesquisa científica e tecnológica.

Parágrafo único - O Poder Público incentivará a pesquisa científica e o ensino científico e tecnológico. (alterado pela EC1)

Título V - Das Disposições Gerais e Transitórias

Art. 177. Fica assegurada a vitaliciedade aos Professores catedráticos e titulares de Ofício de Justiça nomeados até a vigência desta Constituição, assim como a estabilidade de funcionários já amparados pela legislação anterior.

9- Constituição Federal de 1988 (de 5/10/88). As alterações introduzidas pela Emenda Constitucional de Revisão 1 (de 1\%/3/94) e pelas Emendas Constitucionais 10 (de 4/3/96), 11 (de 30/4/96), 14 (de 12/9/96), 17 (de 22/11/97), 19 (de 4/6/98), 20 (de 15/12/98), 26 (de 14/2/00), 27 (21/3/00), 29 (13/9/00), 31, de 14/12/00, 42 (de 19/12/03), 53 (de 19/12/06), 56 (de 20/12/07) e 59 (de 11/11/09) estão em negrito e dentro de caixa.

\section{Capítulo II - Dos Direitos Sociais}

Art. $6^{\circ}$. São direitos sociais a educação, a saúde, o trabalho, o lazer, a segurança, a previdência social, a proteção à maternidade e à infância, a assistência aos desamparados, na forma desta Constituição. 
Art. $6^{\circ}$. São direitos sociais a educação, a saúde, o trabalho, a moradia, o lazer, a segurança, a previdência social, a proteção à maternidade e à infância, a assistência aos desamparados, na forma desta Constituição. (alterado pela EC 26)

Art. $7^{\circ}$. São direitos dos trabalhadores urbanos e rurais, além de outros que visem à melhoria de sua condição social:

XXV - assistência gratuita aos filhos e dependentes desde o nascimento até seis anos de idade em creches e pré-escolas.

XXV - assistência gratuita aos filhos e dependentes desde o nascimento até 5 (cinco) anos de idade em creches e pré-escolas; (alterado pela EC 53)

Art. 22. Compete privativamente à União legislar sobre:

XXIV - diretrizes e bases da educação nacional.

Art. 23. É competência comum da União, dos Estados, do Distrito Federal e dos Municípios:

V - proporcionar os meios de acesso à cultura, à educação e à ciência.

Parágrafo único. Leis complementares fixarão normas para a cooperação entre a União e os Estados, o Distrito Federal e os Municípios, tendo em vista o equilíbrio do desenvolvimento e do bem-estar em âmbito nacional. (acrescentado pela EC 53)

Art. 24. Compete à União, aos Estados e ao Distrito Federal legislar concorrentemente sobre:

IX - educação, cultura, ensino e desporto.

Art. 30. Compete aos Municípios:

VI - manter, com a cooperação técnica e financeira da União e do Estado, programas de educação pré-escolar e de ensino fundamental.

VI - manter, com a cooperação técnica e financeira da União e do Estado, programas de educação infantil e de ensino fundamental; (alterado pela EC 53)

Art. 34. A União não intervirá nos Estados nem no Distrito Federal, exceto para:

(...) VII - assegurar a observância dos seguintes princípios constitucionais:

(...) e) Aplicação do mínimo exigido da receita resultante de impostos estaduais, compreendida a proveniente de transferências, na manutenção e desenvolvimento do ensino. (acrescentado pela EC 14)

e) Aplicação do mínimo exigido da receita resultante de impostos estaduais, compreendida a proveniente de transferências, na manutenção e desenvolvimento do ensino e nas ações e serviços públicos de saúde. (alterado pela EC 29)

Art. 35. O Estado não intervirá em seus Municípios, nem a União nos Municípios localizados em Território Federal, exceto quando:

III - não tiver sido aplicado o mínimo exigido da receita municipal na manutenção e desenvolvimento do ensino;

III - não tiver sido aplicado o mínimo exigido da receita municipal na manutenção e desenvolvimento do ensino e nas ações e serviços públicos de saúde. (alterado pela EC 29)

Art. 37. XVI - é vedada a acumulação remunerada de cargos públicos, exceto, quando houver compatibilidade de horários: 
Art. 37. XVI - é vedada a acumulação remunerada de cargos públicos, exceto, quando houver compatibilidade de horários, observado em qualquer caso o disposto no inciso XI: (alterado pela EC 19)

a) a de dois cargos de professor;

b) a de um cargo de professor com outro técnico ou científico.

Art. 40. O servidor será aposentado:

III - voluntariamente:

b) aos trinta anos de efetivo exercício em funções de magistério, se professor, e vinte e cinco, se professora, com proventos integrais;

Art. 40. (...)

III - voluntariamente, desde que cumprido tempo mínimo de dez anos de efetivo exercício no serviço público e cinco anos no cargo efetivo em que se dará a aposentadoria, observadas as seguintes condições:

a) sessenta anos de idade e trinta e cinco de contribuição, se homem, e cinqüenta de cinco anos de idade e trinta de contribuição, se mulher;

b) sessenta e cinco anos de idade, se homem, e sessenta anos de idade, se mulher, com proventos proporcionais ao tempo de contribuição.

$\S 5^{\circ}$ - Os requisitos de idade e tempo de contribuição serão reduzidos em cinco anos, em relação ao disposto no $\S 1^{\circ}$, III, "a", para o professor que comprove exclusivamente tempo de efetivo exercício das funções de magistério na educação infantil e no ensino fundamental e médio. (alterado pela EC 20)

Art. 150. Sem prejuízo de outras garantias asseguradas ao contribuinte, é vedado à União, aos Estados, ao Distrito Federal e aos Municípios:

VI - instituir impostos sobre:

c) patrimônio, renda ou serviços dos partidos políticos, inclusive suas fundações, das entidades sindicais dos trabalhadores, das instituições de educação e de assistência social sem fins lucrativos, atendidos os requisitos da lei;

$\S 4^{\circ}$ - As vedações expressas no inciso VI, alíneas b e c, compreendem somente o patrimônio, a renda e os serviços relacionados com as finalidades essenciais nelas mencionadas.

Art. 201. $\S 7^{\circ}$ - É assegurada aposentadoria no regime geral da previdência social, nos termos da lei, obedecidas as seguintes condições:

I - trinta e cinco anos de contribuição, se homem, e trinta anos de contribuição, se mulher.

$\S \mathbf{8}^{\circ}$ - Os requisitos a que se refere o inciso I do parágrafo anterior serão reduzidos em cinco anos, para o professor que comprove exclusivamente tempo de efetivo exercício das funções de magistério na educação infantil e no ensino fundamental e médio. (parágrafos e inciso acrescentados pela EC 20)

\section{Capítulo III - Da Educação, da Cultura e do Desporto Seção I - Da Educação}

Art. 205. A educação, direito de todos e dever do Estado e da família, será promovida e incentivada com a colaboração da sociedade, visando ao pleno desenvolvimento da pessoa, seu preparo para o exercício da cidadania e sua qualificação para o trabalho.

Art. 206. O ensino será ministrado com base nos seguintes princípios:

I - igualdade de condições para o acesso e permanência na escola;

II - liberdade de aprender, ensinar, pesquisar e divulgar o pensamento, a arte e o saber; 
III - pluralismo de idéias de concepções pedagógicas, e coexistência de instituições públicas e privadas de ensino;

IV - gratuidade do ensino público em estabelecimentos oficiais;

V - valorização dos profissionais do ensino, garantidos, na forma da lei, planos de carreira para o magistério público, com piso salarial profissional e ingresso exclusivamente por concurso público de provas e títulos, assegurado regime jurídico único para todas as instituições mantidas pela União;

V - valorização dos profissionais do ensino, garantidos, na forma da lei, planos de carreira para o magistério público, com piso salarial profissional e ingresso exclusivamente por concurso público de provas e títulos (alterado pela EC 19)

V - valorização dos profissionais da educação escolar, garantidos, na forma da lei, planos de carreira, com ingresso exclusivamente por concurso público de provas e títulos, aos das redes públicas; (alterado pela EC 53)

VI - gestão democrática do ensino público, na forma da lei;

VII - garantia de padrão de qualidade.

VIII - piso salarial profissional nacional para os profissionais da educação escolar pública, nos termos de lei federal.

Parágrafo único. A lei disporá sobre as categorias de trabalhadores considerados profissionais da educação básica e sobre a fixação de prazo para a elaboração ou adequação de seus planos de carreira, no âmbito da União, dos Estados, do Distrito Federal e dos Municípios. (acrescentado pela EC 53)

Art. 207. As universidades gozam de autonomia didático-científica, administrativa e de gestão financeira e patrimonial, e obedecerão ao princípio de indissociabilidade entre ensino, pesquisa e extensão.

$\S 1^{\circ}$ - É facultado às universidades admitir professores, técnicos e cientistas estrangeiros, na forma da lei.

$\S 2^{\circ}$ - $O$ disposto neste artigo aplica-se às instituições de pesquisa científica e tecnológica. (acrescentado pela EC 11)

Art. 208. O dever do Estado com a educação será efetivado mediante a garantia de:

I - ensino fundamental, obrigatório e gratuito, inclusive para os que a ele não tiveram acesso na idade própria;

I - ensino fundamental, obrigatório e gratuito, assegurada, inclusive, sua oferta gratuita para todos os que a ele não tiverem acesso na idade própria; (alterado pela EC 14)

I - educação básica obrigatória e gratuita dos 4 (quatro) aos 17 (dezessete) anos de idade, assegurada inclusive sua oferta gratuita para todos os que a ela não tiveram acesso na idade própria; (alterado pela EC 59, que prevê a sua implementação progressiva, até 2016, nos termos do Plano Nacional de Educação, com apoio técnico e financeiro da União).

II - progressiva extensão da obrigatoriedade e gratuidade ao ensino médio;

II - progressiva universalização do ensino médio gratuito; (alterado pela EC 14)

III - atendimento educacional especializado aos portadores de deficiência, preferencialmente na rede regular de ensino;

IV - atendimento em creche e pré-escola às crianças de zero a seis anos de idade; 
IV - educação infantil, em creche e pré-escola, às crianças até 5 (cinco) anos de idade;

(alterado pela EC 53)

V - acesso aos níveis mais elevados do ensino, da pesquisa e da criação artística, segundo a capacidade de cada um;

VI - oferta de ensino noturno regular, adequado às condições do educando;

VII - atendimento ao educando, no ensino fundamental, através de programas suplementares de material didático-escolar, transporte, alimentação e assistência à saúde.

VII - atendimento ao educando, em todas as etapas da educação básica, por meio de programas suplementares de material didático-escolar, transporte, alimentação e assistência à saúde. (alterado pela EC 59)

$\S 1^{\circ}$ - O acesso ao ensino obrigatório e gratuito é direito público subjetivo.

$\S 2^{\circ}$ - O não-oferecimento do ensino obrigatório pelo Poder Público, ou sua oferta irregular, importa responsabilidade da autoridade competente.

$\S 3^{\circ}$ - Compete ao Poder Público recensear os educandos no ensino fundamental, fazer-lhes a chamada e zelar, junto aos pais ou responsáveis, pela freqüência à escola.

Art. 209. O ensino é livre à iniciativa privada, atendidas as seguintes condições:

I - cumprimento das normas gerais da educação nacional;

II - autorização e avaliação de qualidade pelo Poder Público.

Art. 210. Serão fixados conteúdos mínimos para o ensino fundamental, de maneira a assegurar formação básica comum e respeito aos valores culturais e artísticos, nacionais e regionais.

$\S 1^{\circ}$ - O ensino religioso, de matrícula facultativa, constituirá disciplina dos horários normais das escolas públicas de ensino fundamental.

$\S 2^{\circ}$ - O ensino fundamental regular será ministrado em língua portuguesa, assegurada às comunidades indígenas também a utilização de suas línguas maternas e processos próprios de aprendizagem.

Art. 211. A União, os Estados, o Distrito Federal e os Municípios organizarão em regime de colaboração seus sistemas de ensino.

$\S 1^{\circ}$ - A União organizará e financiará o sistema federal de ensino e o dos Territórios, e prestará assistência técnica e financeira aos Estados, ao Distrito Federal e aos Municípios para o desenvolvimento de seus sistemas de ensino e o atendimento prioritário à escolaridade obrigatória.

$\S 1^{\circ}$ - A União organizará o sistema federal de ensino e dos Territórios, financiará as instituições de ensino públicas federais e exercerá, em matéria educacional, função redistributiva e supletiva, de forma a garantir equalização de oportunidades educacionais e padrão mínimo de qualidade do ensino mediante assistência técnica e financeira aos Estados, ao Distrito Federal e aos Municípios. (alterado pela EC 14)

$\S 2^{\circ}$ - Os Municípios atuarão prioritariamente no ensino fundamental e pré-escolar.

$\S 2^{\circ}$ - Os Municípios atuarão prioritariamente no ensino fundamental e na educação infantil. (alterado pela EC 14)

$\S 3^{\circ}$ - Os Estados e Distrito Federal atuarão prioritariamente no ensino fundamental e médio. $\S 4^{\circ}$ - Na organização de seus sistemas de ensino, os Estados e os Municípios definirão formas de colaboração, de modo a assegurar a universalização do ensino obrigatório. (acrescentados pela EC 14) 
$\S 4^{\circ}$ - Na organização de seus sistemas de ensino, a União, os Estados, o Distrito Federal e os Municípios definirão formas de colaboração, de modo a assegurar a universalização do ensino obrigatório. (alterado pela EC 59)

$\S 5^{\circ}$ - A educação básica pública atenderá prioritariamente ao ensino regular; (acrescentado pela EC 53)

Art. 212. A União aplicará, anualmente, nunca menos de dezoito, e os Estados, o Distrito Federal e os Municípios, vinte e cinco por cento, no mínimo, da receita resultante de impostos, compreendida a proveniente de transferências, na manutenção e desenvolvimento do ensino.

$\S 1^{\circ}$ - A parcela da arrecadação de impostos transferida pela União aos Estados, ao Distrito Federal e aos Municípios, ou pelos Estados aos respectivos Municípios, não é considerada, para efeito do cálculo previsto neste artigo, receita do governo que a transferir.

$\S 2^{\circ}$ - Para efeito do cumprimento do disposto no caput deste artigo, serão considerados os sistemas de ensino federal, estadual e municipal e os recursos aplicados na forma do art. 213.

$\S 3^{\circ}$ - A distribuição dos recursos públicos assegurará prioridade ao atendimento das necessidades do ensino obrigatório, nos termos do plano nacional de educação.

$\S 3^{\circ}$ - A distribuição dos recursos públicos assegurará prioridade ao atendimento das necessidades do ensino obrigatório, no que se refere à universalização, garantia de padrão de qualidade e equidade, nos termos do plano nacional de educação. (alterado pela EC 59)

$\S 4^{\circ}$ - Os programas suplementares de alimentação e assistência à saúde previstos no art. 208, VII, serão financiados com recursos provenientes de contribuições sociais e outros recursos orçamentários.

$\S 5^{\circ}$ - O ensino fundamental público terá como fonte adicional de financiamento a contribuição social do salário-educação, recolhida, na forma da lei, pelas empresas, que dela poderão deduzir a aplicação realizada no ensino fundamental de seus empregados e dependentes.

$\S 5^{\circ}$ - O ensino fundamental público terá como fonte adicional de financiamento a contribuição social do salário-educação, recolhida pelas empresas, na forma da lei. (alterado pela EC 14)

$\S 5^{\circ}$ - A educação básica pública terá como fonte adicional de financiamento a contribuição social do salário-educação, recolhida pelas empresas na forma da lei. (alterado pela EC 53)

$\S 6^{\circ}$ - As cotas estaduais e municipais da arrecadação da contribuição social do salárioeducação serão distribuídas proporcionalmente ao número de alunos matriculados na educação básica nas respectivas redes públicas de ensino. (acrescentado pela EC 53)

Art. 213. Os recursos públicos serão destinados às escolas públicas, podendo ser dirigidos a escolas comunitárias, confessionais ou filantrópicas, definidas em lei, que

I - comprovem finalidade não-lucrativa e apliquem seus excedentes financeiros em educação;

II - assegurem a destinação de seu patrimônio a outra escola comunitária, filantrópica ou confessional, ou ao Poder Público, no caso de encerramento de suas atividades.

$\S 1^{\circ}$ - Os recursos de que trata este artigo poderão ser destinados a bolsas de estudo para o ensino fundamental e médio, na forma da lei, para os que demonstrarem insuficiência de recursos, quando houver falta de vagas e cursos regulares da rede pública na localidade da residência do educando, ficando o Poder Público obrigado a investir prioritariamente na expansão de sua rede na localidade. $\S 2^{\circ}$ - As atividades universitárias de pesquisa e extensão poderão receber apoio financeiro do Poder Público. 
Art. 214. A lei estabelecerá o plano nacional de educação, de duração plurianual, visando à articulação e ao desenvolvimento do ensino em seus diversos níveis e à integração das ações do Poder Público que conduzam à:

Art. 214. A lei estabelecerá o plano nacional de educação, de duração decenal, com o objetivo de articular o sistema nacional de educação em regime de colaboração e definir diretrizes, objetivos, metas e estratégias de implementação para assegurar a manutenção e desenvolvimento do ensino em seus diversos níveis, etapas e modalidades por meio de ações integradas dos poderes públicos das diferentes esferas federativas que conduzam a: (alterado pela EC 59)

I - erradicação do analfabetismo;

II - universalização do atendimento escolar;

III - melhoria da qualidade do ensino;

IV - formação para o trabalho;

V - promoção humanística, científica e tecnológica do País.

VI - estabelecimento de meta de aplicação de recursos públicos em educação como proporção do produto interno bruto. (acrescentado pela EC 59)

Capítulo IV - Da Ciência e Tecnologia

Art. $218-\S 5^{\circ}-$ É facultado aos Estados e ao Distrito Federal vincular parcela de sua receita orçamentária a entidades públicas de fomento ao ensino e à pesquisa científica e tecnológica.

Capítulo VI - Do Meio Ambiente

Art. 225, $\S 1^{\circ},(\ldots)$ incumbe ao Poder Público:

inciso VI - promover a educação ambiental em todos os níveis de ensino e a conscientização pública para a preservação do meio ambiente.

Art. 227. É dever da família, da sociedade e do Estado assegurar à criança e ao adolescente, com absoluta prioridade, o direito à vida, à saúde, à alimentação, à educação (...)

$\S 3^{\circ}$ - O direito à proteção especial abrangerá os seguintes aspectos:

III - garantia de acesso do trabalhador adolescente à escola.

Das Disposições Constitucionais Gerais

Art. 242. O princípio do Art. 206, IV, não se aplica às instituições educacionais oficiais criadas por lei estadual ou municipal e existentes na data da promulgação desta Constituição, que não sejam total ou preponderantemente mantidas com recursos públicos.

$\S 1^{\circ}$ - O ensino da História do Brasil levará em conta as contribuições das diferentes culturas e etnias para a formação do povo brasileiro.

$\S 2^{\circ}$ - O Colégio Pedro II, localizado na cidade do Rio de Janeiro, será mantido na órbita federal.

Ato das Disposições Constitucionais Transitórias

Art. 19. Os servidores públicos civis da União, dos Estados, do Distrito Federal e dos Municípios, da administração direta, autárquica e das fundações públicas, em exercício na data da promulgação da Constituição, há pelo menos cinco anos continuados, e que não tenham sido admitidos na forma regulada no art. 37 da Constituição, são considerados estáveis no serviço público.

$\S 3^{\circ}$ - O disposto neste artigo não se aplica aos professores de nível superior, nos termos da lei.

Art. 60. Nos dez primeiros anos da promulgação da Constituição, o Poder Público desenvolverá esforços, com a mobilização de todos os setores organizados da sociedade e com a aplicação de, 
pelo menos, cinqüenta por cento dos recursos a que se refere o art. 212 da Constituição, para eliminar o analfabetismo e universalizar o ensino fundamental.

Parágrafo único - Em igual prazo, as universidades públicas descentralizarão suas atividades, de modo a estender suas unidades de ensino superior às cidades de maior densidade populacional.

Art. 60. Nos dez primeiros anos da promulgação desta Emenda, os Estados, o Distrito Federal e os Municípios destinarão não menos de sessenta por cento dos recursos a que refere o art. 212 da Constituição Federal à manutenção e ao desenvolvimento do ensino fundamental, com o objetivo de assegurar universalização de seu atendimento e a remuneração condigna do magistério. (alterado pela EC 14)

$\S 1^{\circ}$ - A distribuição de responsabilidades e recursos entre os Estados e seus Municípios, a ser concretizada com parte dos recursos definidos neste artigo, na forma do disposto no art. 211 da Constituição Federal, é assegurada mediante a criação, no âmbito de cada Estado e do Distrito Federal, de um Fundo de Manutenção e Desenvolvimento do Ensino Fundamental e de Valorização do Magistério, de natureza contábil.

$\S 2^{\circ}$ - O Fundo referido no parágrafo anterior será constituído por, pelo menos, quinze por cento dos recursos a que se referem os art. 155, inciso II, 158, inciso IV, e 159, inciso I, alíneas a e b, e inciso II, da Constituição Federal, e será distribuído entre cada Estado e seus municípios, proporcionalmente ao número de alunos nas respectivas redes de ensino fundamental.

$\S 3^{\circ}$ - A União complementará os recursos dos Fundos a que se refere o par. $1^{\circ}$, sempre que, em cada Estado e no Distrito Federal, seu valor por aluno não alcançar o mínimo definido nacionalmente.

$\S 4^{\circ}$ - A União, os Estados, o Distrito Federal e os Municípios ajustarão progressivamente, em um prazo de cinco anos, suas contribuições ao Fundo, de forma a garantir um valor por aluno correspondente a um padrão mínimo de qualidade de ensino, definido nacionalmente.

$\S 5^{\circ}$ - Uma proporção não inferior a sessenta por cento dos recursos de cada Fundo referido no par. $1^{\circ}$ será destinada ao pagamento dos professores do ensino fundamental em efetivo exercício no magistério.

$\S 6^{\circ}$ - A União aplicará na erradicação do analfabetismo e na manutenção do ensino fundamental, inclusive na complementação a que se refere o par. $3^{\circ}$, nunca menos que o equivalente a trinta por cento dos recursos a que se refere o caput do art. 212 da Constituição Federal.

$\S 7^{\circ}$ - A lei disporá sobre a organização dos Fundos, a distribuição proporcional de seus recursos, sua fiscalização e controle, bem como sobre a forma de cálculo do valor mínimo nacional por aluno. (acrescentados pela EC 14)

Art. 60. Até o $14^{\circ}$ (décimo quarto) ano a partir da promulgação desta Emenda

Constitucional, os Estados, o Distrito Federal e os Municípios destinarão parte dos recursos a que se refere o caput do art. 212 da Constituição Federal à manutenção e desenvolvimento da educação básica e à remuneração condigna dos trabalhadores da educação, respeitadas as seguintes disposições:

I - a distribuição dos recursos e de responsabilidades entre o Distrito Federal, os Estados e seus Municípios é assegurada mediante a criação, no âmbito de cada Estado e do Distrito Federal, de um Fundo de Manutenção e Desenvolvimento da Educação Básica e de Valorização dos Profissionais da Educação - FUNDEB, de natureza contábil;

II - os Fundos referidos no inciso I do caput deste artigo serão constituídos por $20 \%$ (vinte por cento) dos recursos a que se referem os incisos I, II e III do art. 155; o inciso II do caput do art. 157; os incisos II, III e IV do caput do art. 158; e as alíneas a e b do inciso I e o inciso 
II do caput do art. 159, todos da Constituição Federal, e distribuídos entre cada Estado e seus Municípios, proporcionalmente ao número de alunos das diversas etapas e modalidades da educação básica presencial, matriculados nas respectivas redes, nos respectivos âmbitos de atuação prioritária estabelecidos nos $\S \S 2^{\circ}$ e $3^{\circ}$ do art. 211 da Constituição Federal;

III - observadas as garantias estabelecidas nos incisos I, II, III e IV do caput do art. 208 da Constituição Federal e as metas de universalização da educação básica estabelecidas no Plano Nacional de Educação, a lei disporá sobre:

a) a organização dos Fundos, a distribuição proporcional de seus recursos, as diferenças e as ponderações quanto ao valor anual por aluno entre etapas e modalidades da educação básica e tipos de estabelecimento de ensino;

b) a forma de cálculo do valor anual mínimo por aluno;

c) os percentuais máximos de apropriação dos recursos dos Fundos pelas diversas etapas e modalidades da educação básica, observados os arts. 208 e 214 da Constituição Federal, bem como as metas do Plano Nacional de Educação;

d) a fiscalização e o controle dos Fundos;

e) prazo para fixar, em lei específica, piso salarial profissional nacional para os profissionais do magistério público da educação básica;

IV - os recursos recebidos à conta dos Fundos instituídos nos termos do inciso I do caput deste artigo serão aplicados pelos Estados e Municípios exclusivamente nos respectivos âmbitos de atuação prioritária, conforme estabelecido nos $\$ \S 2^{\circ}$ e $3^{\circ}$ do art. 211 da Constituição Federal; V - a União complementará os recursos dos Fundos a que se refere o inciso II do caput deste artigo sempre que, no Distrito Federal e em cada Estado, o valor por aluno não alcançar o mínimo definido nacionalmente, fixado em observância ao disposto no inciso VII do caput deste artigo, vedada a utilização dos recursos a que se refere 0 \$ $5^{\circ}$ do art. 212 da Constituição Federal;

VI - até $10 \%$ (dez por cento) da complementação da União prevista no inciso V do caput deste artigo poderá ser distribuída para os Fundos por meio de programas direcionados para a melhoria da qualidade da educação, na forma da lei a que se refere o inciso III do caput deste artigo;

VII - a complementação da União de que trata o inciso V do caput deste artigo será de, no mínimo:

a) $\mathbf{R}$ \$ 2.000.000.000,00 (dois bilhões de reais), no primeiro ano de vigência dos Fundos;

b) $\mathbf{R} \$ \mathbf{3 . 0 0 0 . 0 0 0 . 0 0 0 , 0 0}$ (três bilhões de reais), no segundo ano de vigência dos Fundos;

c) $\mathbf{R} \$ 4.500 .000 .000,00$ (quatro bilhões e quinhentos milhões de reais), no terceiro ano de vigência dos Fundos;

d) $10 \%$ (dez por cento) do total dos recursos a que se refere o inciso II do caput deste artigo, a partir do quarto ano de vigência dos Fundos;

VIII - a vinculação de recursos à manutenção e desenvolvimento do ensino estabelecida no art. 212 da Constituição Federal suportará, no máximo, 30\% (trinta por cento) da complementação da União, considerando-se para os fins deste inciso os valores previstos no inciso VII do caput deste artigo;

IX - os valores a que se referem as alíneas a, b, e c do inciso VII do caput deste artigo serão atualizados, anualmente, a partir da promulgação desta Emenda Constitucional, de forma a preservar, em caráter permanente, o valor real da complementação da União;

$X$ - aplica-se à complementação da União o disposto no art. 160 da Constituição Federal;

XI - o não-cumprimento do disposto nos incisos V e VII do caput deste artigo importará crime de responsabilidade da autoridade competente; 
XII - proporção não inferior a $60 \%$ (sessenta por cento) de cada Fundo referido no inciso I do caput deste artigo será destinada ao pagamento dos profissionais do magistério da educação básica em efetivo exercício.

$\S 1^{\circ}$ A União, os Estados, o Distrito Federal e os Municípios deverão assegurar, no financiamento da educação básica, a melhoria da qualidade de ensino, de forma a garantir padrão mínimo definido nacionalmente.

$\S 2^{\circ} \mathrm{O}$ valor por aluno do ensino fundamental, no Fundo de cada Estado e do Distrito Federal, não poderá ser inferior ao praticado no âmbito do Fundo de Manutenção e Desenvolvimento do Ensino Fundamental e de Valorização do Magistério - FUNDEF, no ano anterior à vigência desta Emenda Constitucional.

$\S 3^{\circ} \mathrm{O}$ valor anual mínimo por aluno do ensino fundamental, no âmbito do Fundo de Manutenção e Desenvolvimento da Educação Básica e de Valorização dos Profissionais da Educação - FUNDEB, não poderá ser inferior ao valor mínimo fixado nacionalmente no ano anterior ao da vigência desta Emenda Constitucional.

$\S 4^{\circ}$ Para efeito de distribuição de recursos dos Fundos a que se refere o inciso I do caput deste artigo, levar-se-á em conta a totalidade das matrículas no ensino fundamental e considerar-se-á para a educação infantil, para o ensino médio e para a educação de jovens e adultos $1 / 3$ (um terço) das matrículas no primeiro ano, $2 / 3$ (dois terços) no segundo ano e sua totalidade a partir do terceiro ano.

$\S 5^{\circ}$ A porcentagem dos recursos de constituição dos Fundos, conforme o inciso II do caput deste artigo, será alcançada gradativamente nos primeiros 3 (três) anos de vigência dos Fundos, da seguinte forma:

I - no caso dos impostos e transferências constantes do inciso

II do caput do art. 155; do inciso IV do caput do art. 158; e das alíneas a e b do inciso I e do inciso II do caput do art. 159 da Constituição Federal:

a) $\mathbf{1 6 , 6 6 \%}$ (dezesseis inteiros e sessenta e seis centésimos por cento), no primeiro ano;

b) $\mathbf{1 8 , 3 3 \%}$ (dezoito inteiros e trinta e três centésimos por cento), no segundo ano;

c) $20 \%$ (vinte por cento), a partir do terceiro ano;

II - no caso dos impostos e transferências constantes dos incisos I e III do caput do art. 155; do inciso II do caput do art. 157; e dos incisos II e III do caput do art. 158 da Constituição Federal:

a) $6,66 \%$ (seis inteiros e sessenta e seis centésimos por cento), no primeiro ano;

b) $\mathbf{1 3 , 3 3 \%}$ (treze inteiros e trinta e três centésimos por cento), no segundo ano;

c) $20 \%$ (vinte por cento), a partir do terceiro ano. (alterados pela EC 53)

Art. 61. As entidades educacionais a que se refere o art. 213, bem como as fundações de ensino e pesquisa cuja criação tenha sido autorizada por lei, que preencham os requisitos dos incisos I e II do referido artigo e que, nos últimos três anos, tenham recebido recursos públicos, poderão continuar a recebê-los, salvo disposição legal em contrário.

Art. 62. A lei criará o Serviço Nacional de Aprendizagem Rural [SENAR] nos moldes da legislação relativa ao Serviço Nacional de Aprendizagem Industrial [SENAI] e ao Serviço Nacional de Aprendizagem do Comércio [SENAC], sem prejuízo das atribuições dos órgãos públicos que atuam na área.

Art. 64. A Imprensa Nacional e demais gráficas da União, dos Estados, do Distrito Federal e dos Municípios, da administração direta ou indireta, inclusive fundações instituídas e mantidas pelo Poder Público, promoverão edição popular do texto integral da Constituição, que será posta à disposição das escolas e dos cartórios, dos sindicatos, dos quartéis, das igrejas e de outras 
instituições representativas da comunidade, gratuitamente, de modo que cada cidadão brasileiro possa receber do Estado um exemplar da Constituição do Brasil.

Art. 71. Fica instituído, nos exercícios financeiros de 1994 e 1995, o Fundo Social de Emergência, com o objetivo de saneamento da Fazenda Pública Federal e de estabilização econômica, cujos recursos serão aplicados no custeio das ações dos sistemas de saúde e educação (...) (Acrescentado pela EC de Revisão 1, de 1/3/94)

Art. 71. Fica instituído, nos exercícios financeiros de 1994 e 1995, bem assim no período de $1^{\circ}$ de janeiro de 1996 a 30 de junho de 1997, o Fundo Social de Emergência, com o objetivo de saneamento da Fazenda Pública Federal e de estabilização econômica, cujos recursos serão aplicados prioritariamente no custeio dos sistemas de saúde e educação (...)

$\S 2^{\circ}$ O Fundo criado por este artigo passa a ser denominado Fundo de Estabilização Fiscal a partir do início do exercício financeiro de 1996. (Alterado pela EC 10)

Art. 71. É instituído, nos exercícios financeiros de 1994 e 1995 , bem assim nos períodos de $1^{\circ}$ de janeiro de 1996 a 30 de junho de 1997 e $1^{\circ}$ de julho de 1997 a 31 de dezembro de 1999, o Fundo Social de Emergência, com o objetivo de saneamento da Fazenda Pública Federal e de estabilização econômica, cujos recursos serão aplicados prioritariamente no custeio dos sistemas de saúde e educação, incluindo a complementação de recursos de que trata o $\S 3^{\circ}$ do art. 60 do Ato das Disposições Constitucionais Transitórias [a complementação federal para o Fundef] (...) (Alterado pela EC 17)

\section{Art. 72. Integram o Fundo Social de Emergência:}

I - o produto da arrecadação do imposto sobre renda e proventos de qualquer natureza incidente na fonte sobre pagamentos efetuados, a qualquer título, pela União, inclusive suas autarquias e fundações;

II - a parcela do produto da arrecadação do imposto sobre propriedade territorial rural, do imposto sobre renda e proventos de qualquer natureza e do imposto sobre operações de crédito, câmbio e seguro, ou relativas a títulos ou valores mobiliários (...);

III (...)

IV - vinte por cento da arrecadação de todos os impostos e contribuições da União, excetuado o previsto nos incisos I, II e III.

(...)

$\S 2^{\circ}$. As parcelas de que tratam os incisos I, II, III e V serão previamente deduzidas da base de cálculo de qualquer vinculação ou participação constitucional ou legal, não se lhes aplicando o disposto nos arts. 158, II, 159, 212 e 239 da Constituição.

$\S 3^{\circ}$. A parcela de que trata o inciso IV será previamente deduzida da base de cálculo das vinculações ou participações constitucionais previstas nos arts. $153, \S 5^{\circ}, 157$, II, 158, II, 212, e 239 da Constituição. (...)

$\S 4^{\circ} \mathrm{O}$ disposto no parágrafo anterior não se aplica aos recursos previstos no art. 159 da Constituição.

$\S 5^{\circ} \mathrm{A}$ parcela dos recursos provenientes do imposto sobre propriedade territorial rural e do imposto sobre renda e proventos de qualquer natureza, destinada ao Fundo Social de Emergência, nos termos do inciso II deste artigo, não poderá exceder:

I - no caso do imposto sobre propriedade territorial rural, a oitenta e seis inteiros e dois décimos por cento do total do produto da sua arrecadação; 
II - no caso do imposto sobre renda e proventos de qualquer natureza, a cinco inteiros e seis décimos por cento do total do produto da sua arrecadação. (Acrescentado pela Emenda Constitucional de Revisão 1, de 1\%/3/94)

Art. 72. Integram o Fundo Social de Emergência:

(...)

II - a parcela do produto da arrecadação do imposto sobre renda e proventos de qualquer natureza e do imposto sobre operações de crédito, câmbio e seguro, ou relativas a títulos e valores mobiliários, decorrente das alterações produzidas pela Lei $\mathbf{n}^{\circ} 8.894$, de 21 de junho de 1994, e pelas Leis $\mathrm{n}^{\circ} \mathrm{s} 8.849$ e 8.848 , ambas de 28 de janeiro de 1994, e modificações posteriores; (...)

IV - vinte por cento da arrecadação de todos os impostos e contribuições da União, já instituídos ou a serem criados, excetuado o previsto nos incisos I, II e III, observado o disposto nos parágrafos $3^{\circ}$ e $4^{\circ}$. (...)

$\S 2^{\circ}$ - As parcelas de que tratam os incisos I, II, III e V serão previamente deduzidas da base de cálculo de qualquer vinculação ou participação constitucional ou legal, não se lhes aplicando o disposto nos arts. 159, 212 e 239 da Constituição.

$\S 3^{\circ}$ - A parcela de que trata $o$ inciso IV será previamente deduzida da base de cálculo das vinculações ou participações constitucionais previstas nos arts. 153, $\S 5^{\circ}, 157$, II, 212, e 239 da Constituição.

$\S 4^{\circ}$ - O disposto no parágrafo anterior não se aplica aos recursos previstos nos arts. 158, II, e 159 da Constituição.

$\S 5^{\circ}$ - A parcela dos recursos provenientes do imposto sobre renda e proventos de qualquer natureza, destinada ao Fundo Social de Emergência, nos termos do inciso II deste artigo, não poderá exceder a cinco inteiros e seis décimos por cento do total do produto da sua arrecadação. (Alterado pela EC 10).

Art. 76. É desvinculado de órgão, fundo ou despesa, no período de 2000 a 2003, vinte por cento da arrecadação de impostos e contribuições sociais da União, já instituídos ou que vierem a ser criados no referido período, seus adicionais e respectivos acréscimos legais.

$\S 1^{\circ}$ - O disposto no caput deste artigo não reduzirá a base de cálculo das transferências a Estados, Distrito Federal e Municípios na formas dos arts. 153, $5^{\circ}, 157$, I; 158, I e II; e 159, I a e b, e II, da Constituição (...)

$\S 2^{\circ}$ - Excetua-se da desvinculação de que trata o caput deste artigo a arrecadação da contribuição social do salário-educação a que se refere o art. $212, \S 5^{\circ}$, da Constituição. (Acréscimos e alterações introduzidas pela EC 27)

Art. 76. É desvinculado de órgão, fundo ou despesa, no período de 2003 a 2007, vinte por cento da arrecadação da União de impostos, contribuições sociais e de intervenção no domínio econômico, já instituídos ou que vierem a ser criados no referido período, seus adicionais e respectivos acréscimos legais.

$\S 1^{\circ}$ - O disposto no caput deste artigo não reduzirá a base de cálculo das transferências a Estados, Distrito Federal e Municípios na forma dos arts. 153, § $5^{\circ}$; 157, I; 158, I e II; e 159, I, a e b; e II, da Constituição, bem como a base de cálculo das destinações a que se refere o art. 159, I, c, da Constituição. (Alterado pela EC 42. O parágrafo $2^{\circ}$ introduzido pela EC 27 continuou em vigor) 
Art. 76. É desvinculado de órgão, fundo ou despesa, até 31 de dezembro de 2011, $20 \%$ (vinte por cento) da arrecadação da União de impostos, contribuições sociais e de intervenção no domínio econômico, já instituídos ou que vierem a ser criados até a referida data, seus adicionais e respectivos acréscimos legais.

(Alterado pela EC 56. O parágrafo $1^{\circ}$ introduzido pela EC 42 e o $2^{\circ}$ introduzido pela EC 27 continuaram em vigor.

$\S 3^{\circ}$ - Para efeito do cálculo dos recursos para manutenção e desenvolvimento do ensino de que trata o art. 212 da Constituição, o percentual referido no caput deste artigo será de 12,5 $\%$ (doze inteiros e cinco décimos por cento) no exercício de $2009,5 \%$ (cinco por cento) no exercício de 2010, e nulo no exercício de 2011. (acrescentado pela EC 59)

Art. 79. É instituído, para vigorar até o ano de 2010, no âmbito do Poder Executivo Federal, o Fundo de Combate e Erradicação da Pobreza, a ser regulado por lei complementar com o objetivo de viabilizar a todos os brasileiros acesso a níveis dignos de subsistência, cujos recursos serão aplicados em ações suplementares de nutrição, habitação, educação, saúde, reforço de renda familiar e outros programas de relevante interesse social voltados para melhoria da qualidade de vida.

Parágrafo único. O Fundo previsto neste artigo terá Conselho Consultivo e de Acompanhamento que conte com a participação de representantes da sociedade civil, nos termos da lei.

Art. 80. Compõem o Fundo de Combate e Erradicação da Pobreza:

I - a parcela do produto da arrecadação correspondente a um adicional de oito centésimos por cento, aplicável de 18 de junho de 2000 a 17 de junho de 2002, na alíquota da contribuição social de que trata 0 art. 75 do Ato das Disposições Constitucionais Transitórias; II - a parcela do produto da arrecadação correspondente a um adicional de cinco pontos percentuais na alíquota do Imposto sobre Produtos Industrializados - IPI, ou do imposto que vier a substituí-lo, incidente sobre produtos supérfluos e aplicável até a extinção do Fundo; III - o produto da arrecadação do imposto de que trata o art. 153, inciso VII, da Constituição; IV - dotações orçamentárias;

V- doações, de qualquer natureza, de pessoas físicas ou jurídicas do País ou do exterior; VI - outras receitas, a serem definidas na regulamentação do referido Fundo.

$\S 1^{\circ}$ - Aos recursos integrantes do Fundo de que trata este artigo não se aplica o disposto nos arts. 159 e 167, inciso IV, da Constituição, assim como qualquer desvinculação de recursos orçamentários.

$\S 2^{\circ}$ - A arrecadação decorrente do disposto no inciso I deste artigo, no período compreendido entre 18 de junho de 2000 e o início da vigência da lei complementar a que se refere a art. 79, será integralmente repassada ao Fundo, preservado o seu valor real, em títulos públicos federais, progressivamente resgatáveis após 18 de junho de 2002, na forma da lei.

Art. 81. É instituído Fundo constituído pelos recursos recebidos pela União em decorrência da desestatização de sociedades de economia mista ou empresas públicas por ela controladas, direta ou indiretamente, quando a operação envolver a alienação do respectivo controle acionário a pessoa ou entidade não integrante da Administração Pública, ou de participação societária remanescente após a alienação, cujos rendimentos, gerados a partir de 18 de junho de 2002, reverterão ao Fundo de Combate e Erradicação de Pobreza.

$\S 1^{\circ}$ - Caso o montante anual previsto nos rendimentos transferidos ao Fundo de Combate e Erradicação da Pobreza, na forma deste artigo, não alcance o valor de quatro bilhões de 
reais. far-se-à complementação na forma do art. 80, inciso IV, do Ato das disposições Constitucionais Transitórias.

$\S 2^{\circ}$ - Sem prejuízo do disposto no $\S 1^{\circ}$, o Poder Executivo poderá destinar ao Fundo a que se refere este artigo outras receitas decorrentes da alienação de bens da União.

$\S 3^{\circ}$ - A constituição do Fundo a que se refere o caput, a transferência de recursos ao Fundo de Combate e Erradicação da Pobreza e as demais disposições referentes ao $§ 1^{\circ}$ deste artigo serão disciplinadas em lei, não se aplicando o disposto no art. $165, \S 9^{\circ}$, inciso II, da Constituição.

Art. 82. Os Estados, o Distrito Federal e os Municípios devem instituir Fundos de Combate á Pobreza, com os recursos de que trata este artigo e outros que vierem a destinar, devendo os referidos Fundos ser geridos por entidades que contem com a participação da sociedade civil. $\S 1^{\circ}$ - Para o financiamento dos Fundos Estaduais e Distrital, poderá ser criado adicional de até dois pontos percentuais na alíquota do Imposto sobre Circulação de Mercadorias e Serviços - ICMS, ou do imposto que vier a substituí-lo, sobre os produtos e serviços supérfluos, não se aplicando, sobre este adicional, o disposto no art. 158, inciso IV, da Constituição. (Acrescentado pela EC 31)

$\S 1^{\circ}$ - Para o financiamento dos Fundos Estaduais e Distrital, poderá ser criado adicional de até dois pontos percentuais na alíquota do Imposto sobre Circulação de Mercadorias e Serviços - ICMS, sobre os produtos e serviços supérfluos e nas condições definidas na lei complementar de que trata o art. $155, \S 2^{\circ}$, XII, da Constituição, não se aplicando, sobre este percentual, o disposto no art. 158, IV, da Constituição. (Alterado pela EC 42)

$\S 2^{\circ}$ - Para o financiamento dos Fundos Municipais, poderá ser criado adicional de até meio ponto percentual na alíquota do Imposto sobre serviços ou do imposto que vier a substituí-lo, sobre serviços supérfluos.

Art. 83. Lei federal definirá os produtos e serviços supérfluos a que se referem os arts. 80, inciso II, e 82, $\$ \S \mathbf{1}^{\circ} \mathbf{e} 2^{\circ}$. (Acrescentado pela EC 31)

Art. 83. Lei federal definirá os produtos e serviços supérfluos a que se referem os arts. 80, II, e 82, § $\mathbf{2}^{\circ}$. (Alterado pela EC 42) 